RESEARCH ARTICLE

\title{
Antiproliferative Activity and Apoptotic Efficiency of Syzygium cumini Bark Methanolic Extract against EAC Cells In Vivo
}

\author{
Mst. Ayesha Siddika ${ }^{1}$, Plabon K. Das ${ }^{1}$, Saharia Y. Asha ${ }^{1}$, Suraiya Aktar ${ }^{1}$, A.R.M. Tareq ${ }^{2}$, Ayesha Siddika ${ }^{3}$, \\ Md. Abdur Rakib ${ }^{1}$, Farhadul Islam ${ }^{1, *}$ and Jahan Ara Khanam ${ }^{1, *}$ \\ ${ }^{1}$ Department of Biochemistry and Molecular Biology, University of Rajshahi, Rajshahi-6205, Bangladesh; ${ }^{2}$ Environmental and \\ Organic Laboratory, Atomic Energy Centre, Dhaka, Bangladesh; ${ }^{3}$ Institute of Tissue Banking and Biomaterial Research, Atomic \\ Energy Research Establishment, Ganakbari, Savar, Dhaka-1349, Bangladesh
}

\begin{abstract}
Background: Syzygium cumini is one of the evidence-based traditional medicinal plants used in the treatment of various ailments.

Objectives: Herein, the antioxidant property and anticancer property of Syzygium cumini against Ehrlich Ascites Carcinoma (EAC) were examined to find effective chemotherapeutics.

Methods: In vitro assays, and phytochemical and chromatographic analyses were used to determine antioxidant properties and chemical constituents of Syzygium cummini bark methanolic extract (SCBME). Functional assays were used to measure the anticancer activity of SCBME. Fluorescence microscopy and RT-PCR were used to examine morphological and molecular changes of EAC cells followed by SCBME treatment.

Results: Phytochemical and GC-MS analyses confirmed the presence of compounds with antioxidant and anticancer activities. Accordingly, we have noted a strong antioxidant activity of SCBME with an $\mathrm{IC}_{50}$ value of $\sim 10 \mu \mathrm{g} / \mathrm{ml}$. Importantly, SCBME exerted a dose-dependent anticancer activity with significant inhibition of EAC cell growth $(71.08 \pm 3.53 \% ; \mathrm{p}<0.001)$, reduction of tumor burden $(69.50 \% ; \mathrm{p}<0.01)$ and increase of life span $(73.13 \% ; \mathrm{p}<0.001)$ of EAC-bearing mice at $75 \mathrm{mg} / \mathrm{kg} /$ day. Besides, SCBME restored the blood toxicity towards normal in EAC-bearing mice $(\mathrm{p}<0.05)$. SCBME treated EAC cells showed apoptotic features under a fluorescence microscope and fragment DNA in DNA laddering assay. Moreover, up-regulation of the tumor suppressor p53 and pro-apoptotic Bax and down-regulation of $N F-\kappa B$ and anti-apoptotic $B c l-2$ genes implied induction of apoptosis followed by SCBME treatment.
\end{abstract}

A R T I C L E H I S T O R Y
Received: March 10, 2020
Revised: May 20, 2020
Accepted: June 13, 2020
DOI:
10.2174/1871520620666200811122137

Conclusion: The antiproliferative activity of SCBME against EAC cells is likely due to apoptosis, mediated by regulation of p53 and NF-kB signaling. Thus, SCBME can be considered as a useful resource in cancer chemotherapy.

Keywords: Syzygium cumini, bark, anticancer agents, EAC cells, apoptosis, p53.

\section{INTRODUCTION}

Cancer is posing an enormous global threat, a leading cause of death worldwide [1]. Despite the revolutionary advances in therapeutic approaches, the dilemma of emergent resistance upon longterm use and undesired side effects of conventional anti-cancer therapies lead researchers to discover cost-effective, suitable therapeutic options with higher efficacy and lower side effects [2,3].

Nowadays, naturally occurring or plant-derived anticancer agents (alone or synergistically with synthetic agents) are getting more importance in the pharmacological evaluation of cancer therapy $[4,5]$. Plants produce a wide range of active phytochemicals such as flavonoids, phenolics, and polyphenolics, which act as potent antioxidants and are capable of attenuating oxidative stress [6]. Accumulating data suggest that oxidative stress represses apoptosis by inducing $N F-\kappa B$ signaling, and this imbalanced condition could

*Address correspondence to these authors at the Department of Biochemistry and Molecular Biology, University of Rajshahi, Rajshahi-6205, Bangladesh; Tel: +61469857029; Fax +880-721-750064; E-mail: farhad_bio83@ru.ac.bd and Tel: +880-1914-254928; Fax: +880-721-750064;

E-mail: jakbiochem@gmail.com be ameliorated by antioxidants supplementations $[7,8]$. In addition, results from cell cultures and animal studies reported that antioxidant-rich plant materials suppress cancer growth by promoting apoptosis [9-11]. Hence, screening of plant materials to figure out the antioxidant-rich plant and to evaluate its antiproliferative activity with apoptotic efficiency could reveal new potential anticancer drug candidates from natural resources.

Syzygium cumini (L.), commonly known as the Black plum in English is a member of the Mytraceae family [12]. This evergreen tree is native to the Indian subcontinent and an important medicinal plant in various traditional medical applications in Bangladesh [13, 14]. In addition to the dietary use of its ripe fruit, every part of Syzygium cumini, especially the fruits and seeds are extensively used to treat different ailments such as diabetes, gastritis, constipation and diarrhea $[12,13]$. Furthermore, fruits and seeds extracts have anticancer and chemo-preventive activity against breast, cervical and colon cancers [12, 14]. In addition, a number of studies have reported that stem bark of this plant possesses anti-dysenteric, antiviral, anti-rheumatic, and anti-diabetic properties [13]. It is also a rich source of bioactive compounds with antiproliferative properties and can induce apoptosis in cancer cells $[14,15]$. However, to the best of our knowledge, the anticancer activities of Syzygium 
cumini stem bark have never been studied elsewhere. Hence, we hypothesized that Syzygium cumini stem bark methanolic extract (SCBME) might inhibit proliferative activity as well as induce apoptosis of cancer cells. Therefore, in this study, we have investigated the anticancer property of SCBME and its mechanism of action against EAC cells in vivo.

\section{MATERIALS AND METHODS}

\subsection{Chemicals and Reagents}

All the chemicals used in this study were of analytical grade and were purchased from Sigma-Aldrich (St. Louis, MO, USA) unless otherwise mentioned. TIANamp Genomic DNA Kit (TIANGEN, Beijing, China), FvorPrep ${ }^{\mathrm{TM}}$ blood/cultured cell total RNA mini kit (FAVORGEN, Taiwan), Go Script ${ }^{\mathrm{TM}}$ Reverse Transcription System (Promega, USA), Ethidium bromide (Genoxxon bioscience, Germany) and 100 bp DNA ladder (BIORON GmbH, Ludwigshafen, Germany) were of molecular grade.

\subsection{Preparation of Syzygium cumini Barks Methanolic Extract}

Mature Syzygium cumini stem barks were collected from the Rajshahi University campus in July 2018 and authenticated by the Department of Botany, University of Rajshahi, Bangladesh. The collected barks were first washed with distilled water, then chopped into small pieces and shed dried for 25 days. After complete drying, the entire portions were ground into coarse powder and stored in an airtight container at $4^{\circ} \mathrm{C}$ for further use. About $250 \mathrm{~g}$ of the powdered material was taken in a clean borosilicate glass reagent bottle and soaked in $750 \mathrm{ml}$ of Methanol. The container was sealed and kept accompanying shaking and stirring with a magnetic stirrer. After 48 hours, the dissolved portion of the plant sample was separated. About $150 \mathrm{ml}$ methanol was further added and the previous step was repeated. The resulting extract was filtered through Whatman No.1 filter paper and centrifuged at $6000 \mathrm{rpm}$ for 10 minutes. Afterward, the solvent was evaporated under reduced pressure at $42^{\circ} \mathrm{C}$ using a rotary evaporator, and $29.68 \mathrm{~g}(11.87 \%$ yields) SCBME obtained was kept at $4^{\circ} \mathrm{C}$ until further use.

\subsection{Quantitative Phytochemical Analysis}

Total phenolics and flavonoids contents were measured according to the protocol described in our previous study [16]. Total phenolics content of SCBME was expressed in term of gallic acid equivalent, GAE (standard curve equation: $\mathrm{y}=0.0054 \mathrm{x}+0.1112$, $\mathrm{R}^{2}=0.9985$ ), $\mathrm{mg}$ of $\mathrm{GA} / \mathrm{g}$ of dry extract. Total flavonoids content was expressed in term of catechin equivalent, CAE (standard curve equation: $\left.\mathrm{y}=0.0021 \mathrm{x}+0.037, \mathrm{R}^{\mathbf{2}}=0.9951\right), \mathrm{mg}$ of CA/g of dry extract. Similarly, total flavonols and proanthocyanidins in SCBME were estimated as described in our previous study [17]. Total content of flavonols was expressed in term of quercetin equivalent, QUE (standard curve equation $\mathrm{y}=0.002 \mathrm{x}+0.0187, \mathrm{R}^{2}=0.9995$ ), $\mathrm{mg}$ of QU/g of dry extract.

Total content of proanthocyanidins was expressed in terms of catechin equivalent, CAE (standard curve equation: $\mathrm{y}=0.003 \mathrm{x}+$ $0.0185, \mathrm{R}^{2}=0.9921$ ), $\mathrm{mg}$ of $\mathrm{CA} / \mathrm{g}$ of dry extract. $\beta$-carotene, lycopene and anthocyanin contents of SCBME were determined according to Vats et al., 2017 [18].

\subsection{Antioxidant Activity of SCBME}

Antioxidant activity of SCBME was determined following the assays including Total Antioxidant Capacity (TAC), Ferric Reducing Antioxidant Power (FRAP) assay as well as 2, 2-diphenyl-1picryl-hydrazyl (DPPH) and 2'-azino-bis(3-ethylbenzothiazoline-6sulfonic acid) (ABTS) free radical inhibition assays. TAC and FRAP of SCBME were determined by the methods as described in detail in a previous study of our research group [19]. Increased absorbance of the reaction mixture at $695 \mathrm{~nm}$ and $700 \mathrm{~nm}$ for TAC and FRAP, respectively indicated increased antioxidant activity.

DPPH and ABTS free radical scavenging activities of SCBME were determined according to the methods described previously by Das et al., 2019 [16]. Ascorbic acid was used as a reference compound. DPPH and ABTS absorbance at $517 \mathrm{~nm}$ and $734 \mathrm{~nm}$, respectively were taken with a spectrophotometer, using methanol as a blank. Free radical scavenging activities for both DPPH and ABTS were measured using the following formula:

$\%$ of Inhibition $\left.=\left\{\left(\mathrm{A}_{0}-\mathrm{A}\right) / \mathrm{A}_{0}\right)\right\} \times 100$

Where $\mathrm{A}_{0}$ is the absorbance of the control (DPPH/ABTS radical solution without test sample) and $\mathrm{A}$ is the absorbance of the test sample.

\subsection{Gas Chromatography-mass Spectrometry (GC-MS) Analysis}

GC-MS analysis of active compounds from SCBME was carried out by Varian GC (Model Varian CP-3800, USA) with MS (Model: Varian Saturn-2200) spectrometer equipped with a flame ionization detector and capillary column with VF-5 ms $(30 \mathrm{~m} \times 0.25 \mathrm{~mm}, 0.25 \mu \mathrm{m})$. The instrument was operated in electron impact mode at the specified conditions (ionization voltage $-70 \mathrm{eV}$, injector temperature $-250^{\circ} \mathrm{C}$ and detector temperature $-280^{\circ} \mathrm{C}$ ). The carrier gas used was helium at a flow rate of $1 \mathrm{ml} /$ minute and about $1 \mu \mathrm{l}$ of the sample was injected. The temperature program for the column was from $40^{\circ} \mathrm{C}$ ( 1 minute) to $310^{\circ} \mathrm{C}$ at a gradually increased rate of $10^{\circ} \mathrm{C} /$ minute and then held finally $310^{\circ} \mathrm{C}$ for 10 minutes. The chemical compounds and measurements of peak areas were identified by GC-MS NIST LIBRARY (NIST 05).

\subsection{Brine Shrimp Lethality Bioassay}

Cytotoxicity of SCBME was screened against Artemia salina (brine shrimp) nauplii (hatched after 48 hours in saline water) in a 1-day in vivo bioassay according to a published protocol [17]. Concentrations of SCBME and gallic acids (standard) were 12.5, 25, 50,100 , and $200 \mu \mathrm{g} / \mathrm{ml}$ with a final volume of $5 \mathrm{ml}$ in each vial in triplicates.

\subsection{Experimental Animal, Cell Lines and Ethical Clearance}

Healthy male Swiss albino mice, $6-7$ weeks old $(25 \pm 2 \mathrm{~g}$ body weight) were collected from the animal house of the Department of Pharmacy, University of Jahangirnagar, Dhaka, Bangladesh.

The initial inoculums of EAC cells were obtained from the Indian Institute of Chemical Biology (IICB), Kolkata, India. The culture and aspiration of EAC cells were maintained in our laboratory as ascites tumor in Swiss albino mice by intraperitoneal inoculation bi-weekly. The use of mice as an animal model for cancer research was approved by the Institutional Animal, Medical Ethics, Bio-Safety and Bio-Security Committee (IAMEBBC) for Experimentations on Animal, Human, Microbes, and Living Natural Sources (No. 125/320-IAMEBBC/IBSc), Institute of Biological Sciences, University of Rajshahi, Bangladesh.

\subsection{Determination of Anticancer Properties of SCBME}

\subsubsection{Determination of Median Lethal Dose $\left(L D_{50}\right)$}

$\mathrm{LD}_{50}$ was determined according to the protocol described previously [20]. In short, SCBME was dissolved in 2\% DMSO in PBS and injected intraperitoneally to six groups of mice $(n=6)$ at various doses. Toxicity was evaluated by recording mortality after 24 hours.

\subsubsection{Determination of EAC Cell Growth Inhibition (in vivo)}

To determine the cell growth inhibition, $100 \mu 1 \mathrm{EAC}$ cells from $2 \times 10^{6}$ cells $/ \mathrm{ml}$ PBS were injected into the peritoneal cavity of the five groups of Swiss albino mice $(n=6)$ at day ' 0 ' [21]. Treatments were started after 24 hours of tumor inoculation and continued for 
five consecutive days. Group I was used as control receiving solvent only, Group II - IV received SCBME at the doses of 25, 50 and $75 \mathrm{mg} / \mathrm{kg}$ per day and Group $\mathrm{V}$ was treated with bleomycin at the dose of $0.3 \mathrm{mg} / \mathrm{kg}$. On the $6^{\text {th }}$ day of treatment, cells were collected and viable cells were first identified with Trypan blue and then counted with a hemocytometer under an inverted microscope (XDS-1R, Optika, South Korea). Cell growth inhibition was calculated by the following formula:

$\%$ Cell growth inhibition $=\left(1-\frac{T w}{C w} \times 100\right)$

Where $\mathrm{Tw}=$ mean number of tumor cells of treated groups and $\mathrm{CW}=$ mean number of tumor cells of control.

\subsubsection{Determination of Average Tumor Weight and Survival Time}

This experiment was conducted according to a method previously described by Islam et al., 2013[22]. For therapeutic evaluation, $100 \mu 1$ of EAC cells from adjusted $2 \times 10^{6}$ cells $/ \mathrm{ml}$ was inoculated per mouse to five groups of mice $(n=6)$ on the day ' 0 '. Treatments were started after 24 hours of tumor inoculation and continued for 10 days. Tumor growth was monitored by recording daily weight change up to 20 days. Host survival was recorded and expressed as mean survival time in days and percent (\%) increase of life span was calculated by using the following formula:

Mean survival time (MST)

$=\underline{\sum \text { Survival time (days) of each mouse in a group }}$ Total number of mice

Per cent increase of life span (ILS) \%

$=\left(\frac{\text { MST of treated group }}{\text { MST of control group }}-1\right) \times 100$

\subsubsection{Estimation of Hematological Parameters}

Hematological parameters (Hemoglobin, RBC and WBC) were measured as described by Ruksana et al., 2019 with slight modification [23]. A comparison was made among six groups $(n=6)$ of mice on the $11^{\text {th }}$ day after inoculation. All the groups were first injected with EAC cells $\left(0.1 \mathrm{ml}\right.$ of $2.0 \times 10^{6}$ cells/mouse $)$ except the normal group. After 24 hours of inoculation, PBS $(0.1 \mathrm{ml} / \mathrm{kg} / \mathrm{mouse} /$ day $)$ was administered to normal and EAC control, respectively, for 10 days. Then, SCBME at doses of $25,50,75 \mathrm{mg} / \mathrm{kg} / \mathrm{mouse}$ and bleomycin $(0.3 \mathrm{mg} / \mathrm{kg})$, were administered. On the $11^{\text {th }}$ day after EAC cell inoculation, hematological parameters were measured from freely flowing tail vein blood of each mouse of each group by using cell dilution fluid. Total WBC and RBC were counted by a microscope with a hemocytometer, and the percentage of hemoglobin (Hb) was measured by Sahli's haemometer.

\subsection{Evaluation of Apoptotic Efficiency of SCBME}

\subsubsection{Observation of the Morphological Appearances and} Nuclear Damages of EAC Cells

The study of cellular apoptosis was carried out by observation of morphological changes of EAC cells from both control and treated mice using a fluorescence microscope (Olympus iX71, Japan) followed by staining the cells with 4', 6-diamidino-2-phenylindole (DAPI) [24]. In brief, EAC cells were collected from both control and treated $(75 \mathrm{mg} / \mathrm{kg})$ mice after 5 days of treatment and the cells were washed 2-3 times with PBS. $0.15 \%$ of Triton-X-100 was added and incubated at $37^{\circ} \mathrm{C}$ for 10 minutes in dark to make the cell membrane permeable to DAPI. Subsequently, the cells were stained with $5 \mu 1$ of $1 \mathrm{mg} / \mathrm{ml}$ of DAPI solution and incubated in dark at $37^{\circ} \mathrm{C}$ for 10 minutes. Finally, the cells were washed with PBS and resuspended in PBS for observation of morphological changes under a fluorescence microscope.

\subsubsection{DNA Fragmentation Assay}

To observe the nucleotide cleavage, DNA fragmentation assay was carried out followed by SCBME treatment [22]. Total genomic DNA was extracted from control and treated $(75 \mathrm{mg} / \mathrm{kg})$ EAC cells using TIANamp Genomic DNA kit (Tiangen, Beijing, China) according to the manufacturer's protocol. DNA was run on $1 \%$ agarose gel containing $0.1 \%$ ethidium bromide and visualized under UV-light.

\subsubsection{Gene Expression Analysis by Reverse Transcriptase Polym- erase Chain Reaction (RT-PCR)}

Total RNA from both treated $(75 \mathrm{mg} / \mathrm{kg})$ and untreated (control) EAC cells were isolated using an RNA extraction kit (Favorgen, Taiwan) following the manufacturer's guidelines. Two $\mu \mathrm{g}$ total RNA was converted into cDNA by using $1 \mu 1$ Random Primer, $2 \mu 1$ $2.5 \mathrm{mM} \mathrm{MgCl}_{2}, 1 \mu 1 \mathrm{GoScript}^{\mathrm{TM}}$ Reverse Transcriptase, $1 \mu 1 \mathrm{PCR}$ Nucleotide Mix (final concentration $0.5 \mathrm{mM}$ each dNTP), $4 \mu$ l GoScript ${ }^{\mathrm{TM}} 5 \mathrm{X}$ Reaction Buffer and required amount of Nuclease-free water to a final volume of $20 \mu 1$ (Promega, Madison-Wisconsin, USA).

Expression of $p 53, B a x, B c l-2$ and $N F-\kappa B$ were studied by RTPCR as described by Zahan et al., 2019 [25]. GAPDH, a housekeeping gene, was also studied as an internal control. The sequences of the primer used in the experiment are given in Table $\mathbf{1}$. Each $10 \mu 1$ of PCR reaction mixture contained $5 \mu 1$ of master mix (Promega, Madison-Wisconsin, USA), $1 \mu 1$ each of forward and reverse primer, and template of $1 \mu 1$ and $2 \mu 1$ of nuclease-free water. Reaction conditions were initial PCR activation step of 2 minutes and $10 \mathrm{sec}$ at $95^{\circ} \mathrm{C}$, followed by 35 cycles of $95^{\circ} \mathrm{C}$ for $45 \mathrm{sec}, 52^{\circ} \mathrm{C}$ for $45 \mathrm{sec}$, and $72^{\circ} \mathrm{C}$ for $45 \mathrm{sec}$ and a final extension of $72^{\circ} \mathrm{C}$ for 5 minutes. The annealing temperature for $N F-\kappa B$ was $48^{\circ} \mathrm{C}$ instead of $52^{\circ} \mathrm{C}$. For analyzing the PCR reactions, PCR products were analyzed on $1 \%$ agarose gel staining with $0.1 \%$ ethidium bromide and visualized in UV-trans-illuminator (Cleaver bioscience, UK).

\subsection{Statistical Analysis}

All analyses were carried out in triplicates and data were expressed as mean $\pm \mathrm{SD}$ (Standard deviation). Statistical analysis was performed with one-way analysis of variance (ANOVA) followed by Dunnett's ' $t$ ' test for anticancer activity and Duncan's multiple range test (DMRT) for antioxidant activity using Statistical Package for Social Science (SPSS) statistical software of v16 version. $\mathrm{p}<0.05$ was considered to be statistically significant.

Table 1. The sequence of primers used for PCR amplification.

\begin{tabular}{|c|c|c|}
\hline Gene Name & Primer Sequence & Annealing Temperature \\
\hline \hline$G A P D H$ & Forward: (5'-GTGGAAGGACTCATGACCACAG-3') Reverse: (5'-CTGGTGCTCAGTGTAGCCCAG-3') & $52^{\circ} \mathrm{C}$ \\
\hline$p 53$ & Forward: (5'-CACAAAAACAGGTTAAACCCAG-3') Reverse: (5'-AGCACATAGGAGGCAGAGAC-3') & $52^{\circ} \mathrm{C}$ \\
\hline$B c l-2$ & Forward: (5'-GTGGAGGAGCTCTTCAGGGA-3') Reverse: (5'-AGGCACCCAGGGTGATGCAA-3') & $52^{\circ} \mathrm{C}$ \\
\hline$B a x$ & Forward: (5'-GGCCCACCAGCTCTGAGCAGA-3') Reverse: (3'-GCCACGTGGGCGTCCCAAAGT-5') & $52^{\circ} \mathrm{C}$ \\
\hline$N F-\kappa B$ & Forward: (5'-AACAAAATGCCCCACGGTTA-3') Reverse: (3'-GGGACGATGCAATGGACTGT-5') & $48^{\circ} \mathrm{C}$ \\
\hline
\end{tabular}




\section{RESULTS}

\subsection{Phytochemical Constituents of SCBME}

The qualitative phytochemical screening of extract showed the presence of phenols and flavonoids as major contents in the obtained extract (Table 2). The order of polyphenols content in SCBME was TPC $>$ TFC $>$ TPRC $>$ TFLC. Also, SCBME contains a considerable amount of $\beta$-carotene, lycopene, and anthocyanin of $2.54,0.05$, and $0.23 \mathrm{mg} / \mathrm{g}$, respectively.

\subsection{Chemical Composition of SCBME}

GC-MS analysis of SCBME enabled the identification of 23 compounds (Table 3) (Fig. 1) of different chemical families. The compounds were accounted for $95.33 \%$ of total plant extract.

\subsection{SCBME Possesses Strong Antioxidant Activity in vitro}

SCBME showed a dose-dependent antioxidant activity $(\mathrm{p}<0.05)$ (Fig. 2). In total antioxidant capacity (TAC) assay, the absorbance of SCBME $(400 \mu \mathrm{g} / \mathrm{ml})$ and ascorbic acid was $0.546 \pm 0.010$ and $1.118 \pm 0.006$, respectively (Fig. 2a). In Ferric Reducing Antioxidant Power (FRAP) assay, the absorbance of SCBME increased in a concentration-dependent manner, which was comparable to ascorbic acid (Fig. 2b). SCBME exhibited significant $(\mathrm{p}<0.05)$ concentrationdependent scavenging activity against 2, 2-diphenyl-1-picryl-hydrazyl (DPPH) (Fig. 2c) and 2, 2'-azino-bis (3-ethylbenzothiazoline-6sulfonic acid) (ABTS) (Fig. 2d) free radical. The $\mathrm{IC}_{50}$ values of SCBME and ascorbic acid against DPPH were 11.04 and $9.02 \mu \mathrm{g} / \mathrm{ml}$ as well as against ABTS were 9.56 and $7.46 \mu \mathrm{g} / \mathrm{ml}$, respectively.

\subsection{Toxicity of SCBME Against Brine Shrimp and Swiss Al- bino Mice}

SCBME showed moderate cytotoxic activity with a median lethal concentration $\left(\mathrm{LC}_{50}\right)$ value of $98.07 \mu \mathrm{g} / \mathrm{ml}$ in comparison with gallic acid, whose $\mathrm{LC}_{50}$ value was $81.48 \mu \mathrm{g} / \mathrm{ml}$ (Table 4).

$\mathrm{LD}_{50}$ of SCBME was found to be $1050 \mathrm{mg} / \mathrm{kg}$ body weight for intraperitoneal treatment in male Swiss albino mice.

\subsection{SCBME Significantly Inhibits Cancer Cells Growth and Proliferation}

The effect of SCBME on EAC cell growth is shown in Fig. 3a. The maximum cell growth inhibition with SCBME was noted at the dose of $75 \mathrm{mg} / \mathrm{kg} /$ day $(71.08 \%)$ compared with the control mice,

Table 2. Amounts of different Polyphenols and bioactive phytochemical constituents in SCBME.

\begin{tabular}{|c|c|c|c|c|c|c|c|}
\hline Phytochemicals & Phenolics $^{\mathrm{a}}$ & Flavonoids $^{\mathrm{b}}$ & Flavonol $^{\mathrm{c}}$ & $\begin{array}{l}\text { Proantho- } \\
\text { cyanidins }\end{array}$ & $\begin{array}{l}\text { Lycopene } \\
(\mathrm{mg} / \mathrm{g})\end{array}$ & $\begin{array}{c}\beta \text {-carotene } \\
(\mathrm{mg} / \mathrm{g})\end{array}$ & $\begin{array}{l}\text { Anthocyanin } \\
(\mathrm{mg} / \mathrm{g})\end{array}$ \\
\hline Amounts in SCBME & $136.64 \pm 0.62$ & $117.42 \pm 1.04$ & $82.60 \pm 1.26$ & $54.67 \pm 0.76$ & $0.05 \pm 0.01$ & $2.56 \pm 0.04$ & $0.23 \pm 0.06$ \\
\hline
\end{tabular}

Note: Results were expressed as mean $\pm \mathrm{SD}(\mathrm{n}=3)$. $\mathrm{a}, \mathrm{b}$ and $\mathrm{c}$ expressed in terms of GAE, CAE and QUE, respectively (mg of GAE, CAE and QUE/g of dry extract, respectively).

Table 3. Chemical composition of SCBME analyzed by GC/MS.

\begin{tabular}{|c|c|c|c|}
\hline S. No. & Compounds & Retention Time (Minutes) & Area (\%) \\
\hline 1 & 2-butoxy-Ethanol & 5.07 & 49.35 \\
\hline 2 & Cyclohexanone & 6.31 & 0.72 \\
\hline 3 & 1,2,3,5-tetramethyl-Benzene & 10.57 & 1.41 \\
\hline 4 & Cyclohexasiloxane, dodecamethyl- & 13.57 & 0.63 \\
\hline 5 & $\begin{array}{c}\text { 2-Butenoic acid, 2-methyl-, 1,1a,1b,4,4a,5,7a,7b,8,9-decahydro-4a,7b-dihydroxy-3-(hydroxymethyl)-1,1,6,8- } \\
\text { tetramethyl-5-oxo-9aH-cyclopropa[3,4]benz[1,2-e]azulene-9,9a-diyl ester, [1aR-[1a.alpha.,1b.beta.,4a.beta., } \\
\text { 7a.alpha.,7b.alpha.,8.alpha.,9.beta. (E),9a.alpha.(E)]]- }\end{array}$ & 48.31 & 0.16 \\
\hline 6 & 2,4-Imidazolidinedione, 5-[3,4-bis[(trimethylsilyl)oxy]phenyl]-3-methyl-5-phenyl-1-(trimethylsilyl)- & 50.09 & 7.13 \\
\hline 7 & .psi.,.psi.-Carotene, 3,3',4,4'-tetradehydro-1,1',2,2'-tetrahydro-1-hydroxy-1'-methoxy- & 50.58 & 1.42 \\
\hline 8 & 9,10-Anthracenedione, 1-(methylamino)-4-[(4-methylphenyl)amino]- & 50.81 & 1.59 \\
\hline 9 & Acetic acid, 1,1',4'-triacetoxy-5,5'-diisopropyl-6,7,6',7'-tetramethoxy-3,3'-dimethyl-[2,2']binaphthalenyl-4-yl ester & 51.19 & 2.16 \\
\hline 10 & 3,9.beta.;14,15-Diepoxypregn-16-en-20-one, 3,11.beta.,18-triacetoxy- & 51.33 & 3.77 \\
\hline 11 & Canthaxanthin & 51.49 & 3.59 \\
\hline 12 & Cephalotaxine, 11-(acetyloxy)-, acetate (ester), (11.alpha.)- & 51.57 & 3.74 \\
\hline 13 & $\begin{array}{c}\text { 1H-Cyclopent[c]isoxazole, 1-[2,3:5,6-bis-O-(1-methylethylidene)-.alpha.-d-mannofuranosyl]hexahydro-4,5,6- } \\
\text { tris(phenylmethoxy)-, [3aR -(3a.alpha.,4.alpha.,5.beta., }\end{array}$ & 51.87 & 5.37 \\
\hline 14 & 9-15Desoxo-9-x-acetoxy-3,8,12-tri-O-acetylingol & 52.12 & 3.57 \\
\hline 15 & Spiro[9,9']difluorene, 2,2'-(2,5,8,11-tetraoxadodecane-1,12-diyl)- & 52.44 & 3.81 \\
\hline 16 & 3,8,12-Tri-O-acetylingol 7-phenylacetate & 55.95 & 1.47 \\
\hline 17 & 2H-1,4-Benzodiazepin-2-one, 7-chloro-1,3-dihydro-1-methyl-5-[4-[(trimethylsilyl)oxy]phenyl]- & 56.01 & 0.51 \\
\hline 18 & alpha.-Lumicolchicine & 56.31 & 1.55 \\
\hline 19 & Pregn-16-en-20-one, 11,18-bis(acetyloxy)-3,9-epoxy-3-methoxy-, (3.alpha.,5.beta.,11.alpha.)- & 57.68 & 0.51 \\
\hline 20 & 3-Hydroxybromoazepam, bis(trimethylsilyl)- deriv & 57.84 & 0.62 \\
\hline 21 & 6,6'-Diacetyl-7,7'-dihydroxy-2,2',4,4',5,5'-hexamethoxy-1,1'-binaphthalene & 58.73 & 1.31 \\
\hline 22 & Pregnane-11,20-dione, 3,17,21-tris[(trimethylsilyl)oxy]-, 20-[O-(phenylmethyl)oxime], (3.alpha.,5.alpha.)- & 59.23 & 0.62 \\
\hline 23 & Silane, [[(3.beta.,5.alpha.,11.beta.,20S)-pregnane-3,11,17,20,21-pentayl]pentakis(oxy)]pentakis[trimethyl- & 60.27 & 0.32 \\
\hline
\end{tabular}




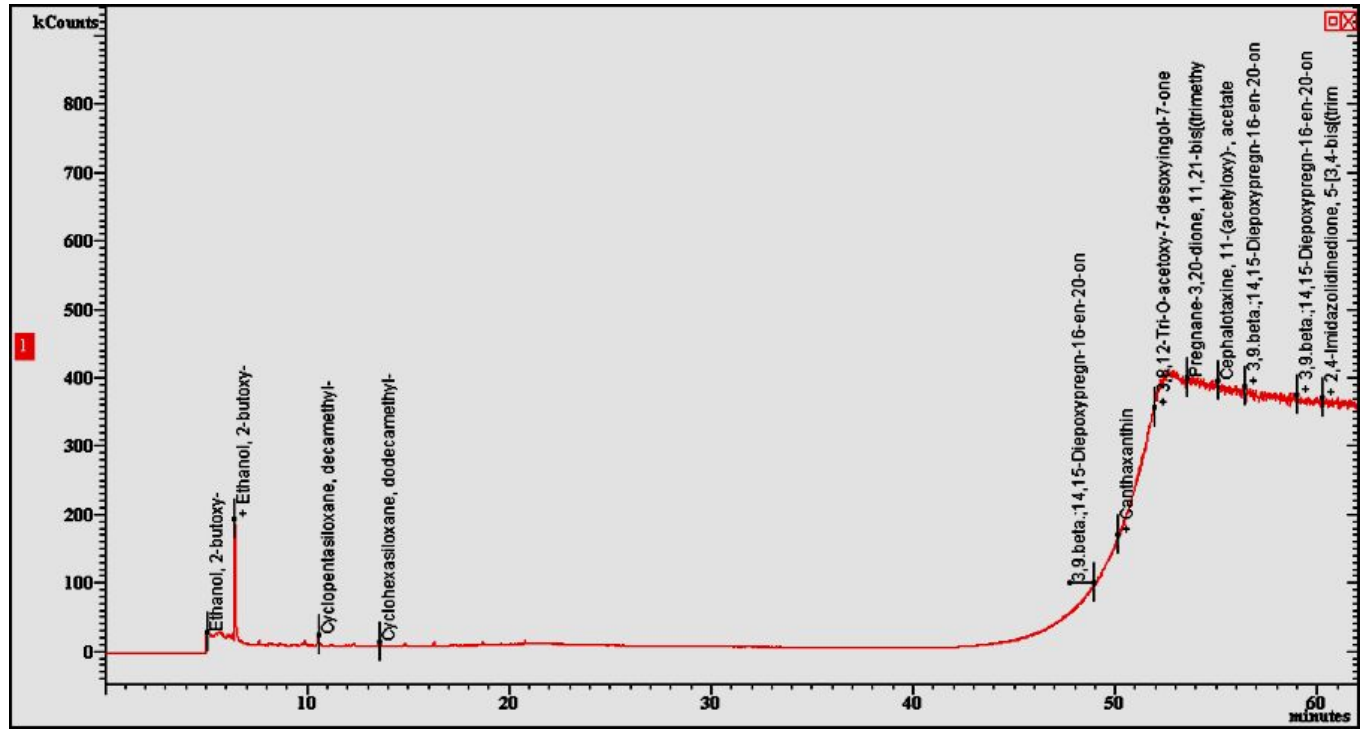

Fig. (1). GC-MS chromatogram of SCBME. (A higher resolution / colour version of this figure is available in the electronic copy of the article).

(a)

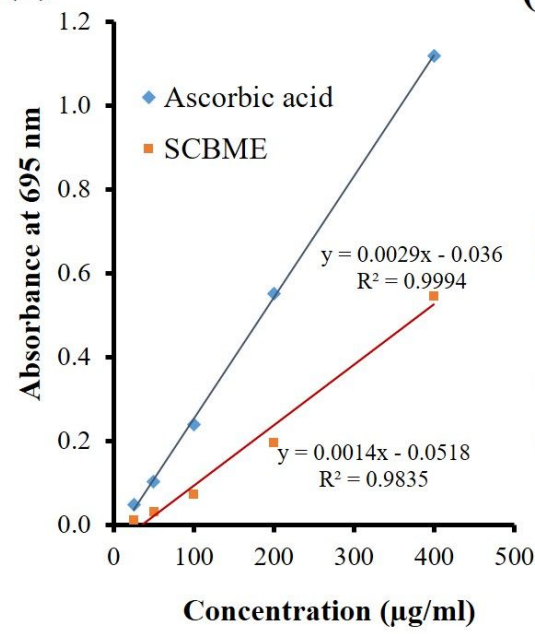

(b)

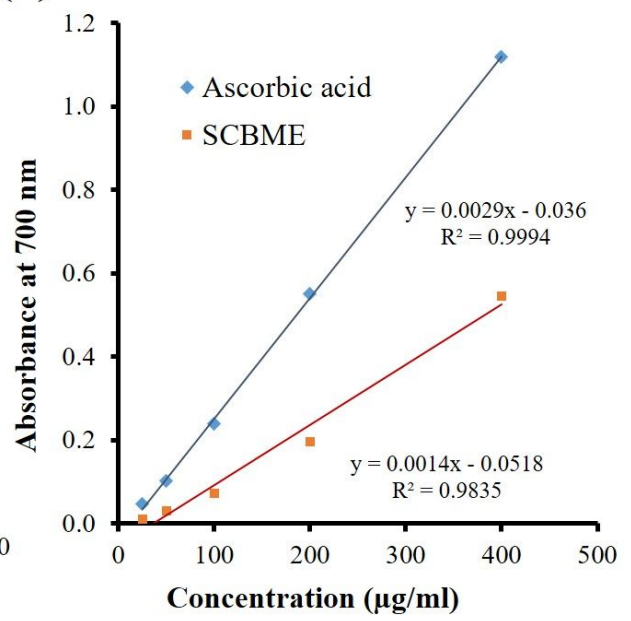

(c)

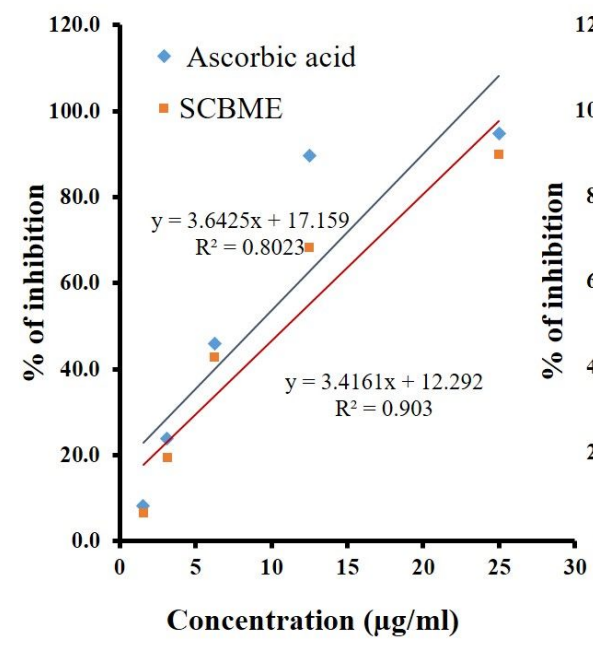

(d)

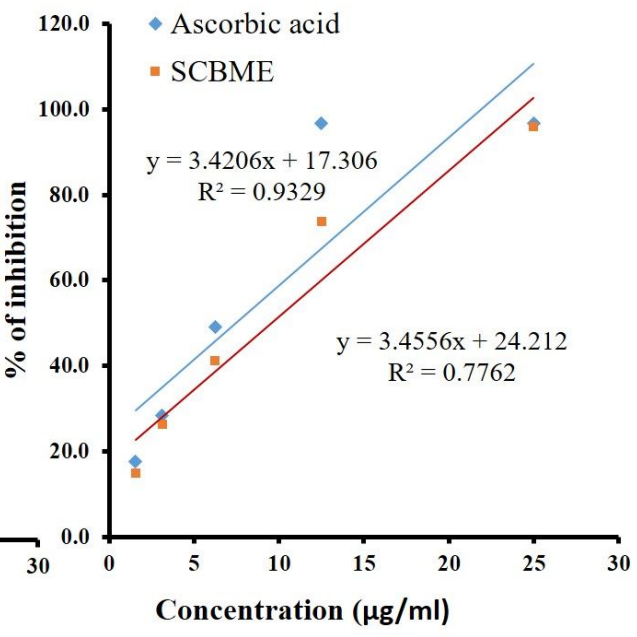

Fig. (2). Antioxidant activity of SCBME. (a) Total antioxidant capacity of SCBME and ascorbic acid; (b) Ferric reducing antioxidant power assay of SCBME and Ascorbic acid; (c) DPPH free radical inhibition activity of SCBME and Ascorbic acid; (d) ABTS free radical inhibition activity of SCBME and Ascorbic acid. (A higher resolution / colour version of this figure is available in the electronic copy of the article). 
Table 4. Concentration dependent cytotoxic potential of SCBME and standard gallic acid against Brine shrimp nauplii.

\begin{tabular}{|c|c|c|c|}
\hline Test Sample & LC $_{\mathbf{5 0}}(\boldsymbol{\mu g} / \mathbf{m l})$ & $\mathbf{9 5 \%}$ Confidence Limits $(\boldsymbol{\mu g} / \mathbf{m l})$ & Regression Equation \\
\hline \hline Gallic acid & $81.48 \pm 0.47$ & 45.113 to 147.178 & $\mathrm{y}=2.239+1.44 \mathrm{x}$ \\
\hline SCBME & $98.07 \pm 0.39$ & 49.99 to 192.41 & $\mathrm{y}=2.054+1.47 \mathrm{x}$ \\
\hline
\end{tabular}

(a)

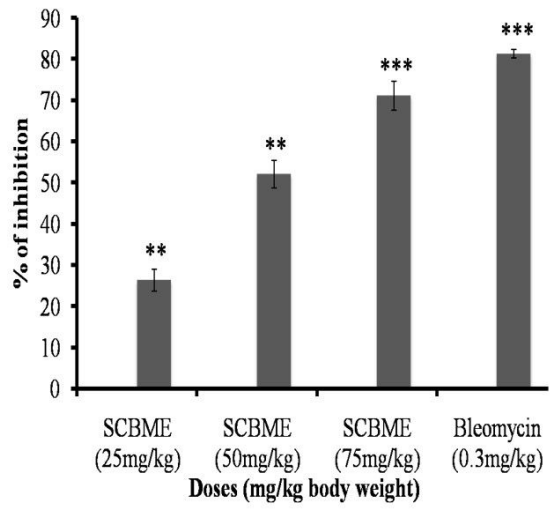

(b)

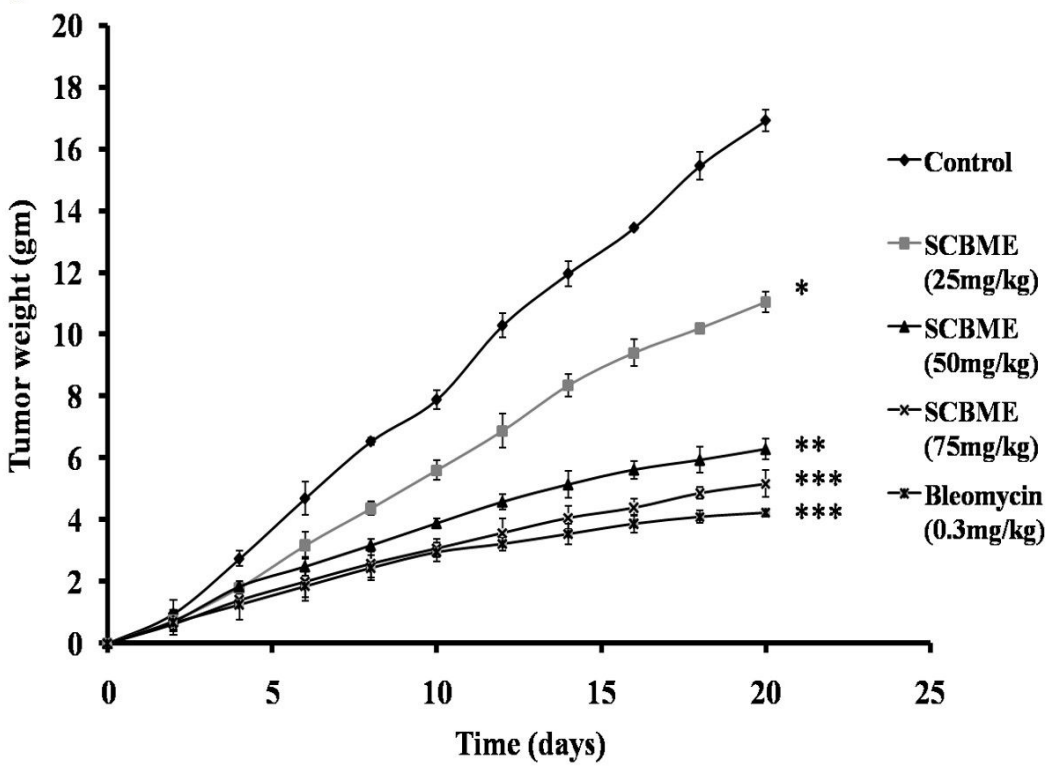

(c)

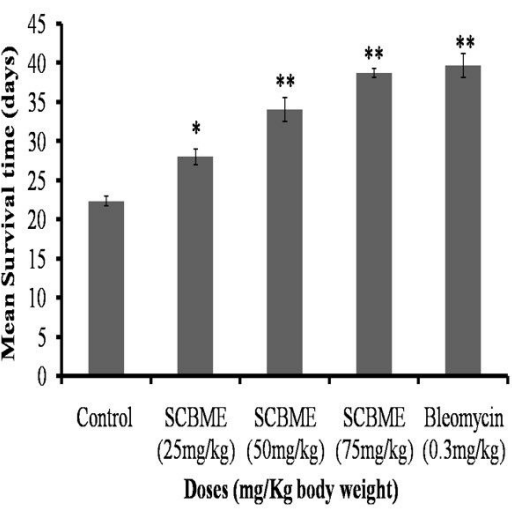

Fig. (3). Anticancer activity of SCBME. (a) Effects of SCBME on EAC cell growth inhibition; (b) Tumor weight of EAC bearing mice treated with SCBME; (c) Effects of SCBME on survival time of tumour-bearing mice. Results are shown as mean $\pm \mathrm{SD}(\mathrm{n}=6)$, where significant values are *p<0.05, $* * \mathrm{p}<0.01$ and $* * * \mathrm{p}<0.001$ when treated (EAC+SCBME) mice compared with EAC bearing control mice (EAC only). (A higher resolution / colour version of this figure is available in the electronic copy of the article).

where bleomycin (a clinically used anticancer drug) treated mice showed cell growth inhibition of $80.15 \%(0.3 \mathrm{mg} / \mathrm{kg} / \mathrm{day})$.

It was noted that the treatment of SCBME on EAC-cells bearing mice resulted in dose-dependent inhibition of tumor growth, which is represented in Fig. 3b. In the case of the control group, tumor weight was increased by $16.92 \mathrm{~g}$ after 20 days compared to the normal. However, treatment with SCBME at doses 25, 50 and $75 \mathrm{mg} / \mathrm{kg}$ (i.p.) increased tumor weight by $11.04,6.28$, and $5.16 \mathrm{~g}$, respectively. Therefore, treatment with SCBME at the doses 25,50 , and $75 \mathrm{mg} / \mathrm{kg}$ decreased tumor burden of EAC cell bearing mice by $34.75 \%, 62.88 \%$, and $69.50 \%$ respectively, compared to the control. Mean survival time and life span of tumor-bearing mice 
Table 5. Effect of SCBME on blood parameters of tumour bearing and normal mice on day 11 of tumour inoculation.

\begin{tabular}{|c|c|c|c|}
\hline Group & $\%$ of $\mathrm{Hb}(\mathrm{gm} / \mathrm{dl})$ & RBC (Cells/ml) & WBC (Cells/ml) \\
\hline Normal mice & $13.76 \pm 0.50$ & $(6.78 \pm 0.19) \times 10^{9}$ & $(11.60 \pm 0.36) \times 10^{6}$ \\
\hline $\begin{array}{c}\text { Control } \\
\text { (EAC cell bearing mice) }\end{array}$ & $6.17 \pm 0.61^{*}$ & $(3.1 \pm 0.34) \times 10^{9 *}$ & 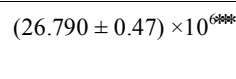 \\
\hline $\begin{array}{c}\mathrm{EAC}+\mathrm{SCBME}(25 \mathrm{mg} / \mathrm{kg}) \\
\mathrm{EAC}+\operatorname{SCBME}(50 \mathrm{mg} / \mathrm{kg}) \\
\mathrm{EAC}+\mathrm{SCBME}(75 \mathrm{mg} / \mathrm{kg}) \\
\mathrm{EAC}+\text { Bleomyci } \\
(0.3 \mathrm{mg} / \mathrm{kg})\end{array}$ & $\begin{array}{l}8.87 \pm 0.31^{*} \\
11.57 \pm 0.25^{*} \\
13.13 \pm 0.59^{* *} \\
13.72 \pm 0.70^{* *}\end{array}$ & $\begin{array}{l}(4.56 \pm 0.22) \times 10^{9 *} \\
(5.65 \pm 0.13) \times 10^{9 *} \\
(6.1 \pm 0.09) \times 10^{9 *} \\
(6.72 \pm 1.6) \times 10^{9 *}\end{array}$ & 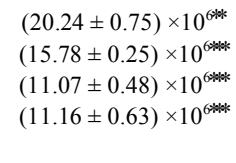 \\
\hline
\end{tabular}

Results are shown as mean \pm SD (standard deviation) $(n=6)$, where control mice (EAC only) were compared with normal mice (no EAC) and treated mice $($ EAC + SCBME) were compared with control mice. The significant values are $* \mathrm{p}<0.05, * * \mathrm{p}<0.01$ and $* * * \mathrm{p}<0.001$.

(a)
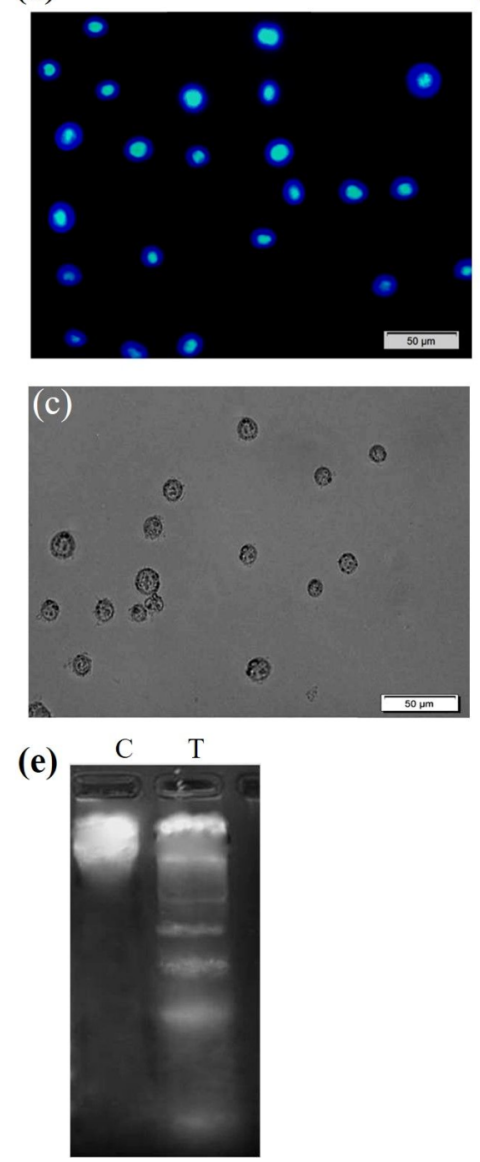

(b)
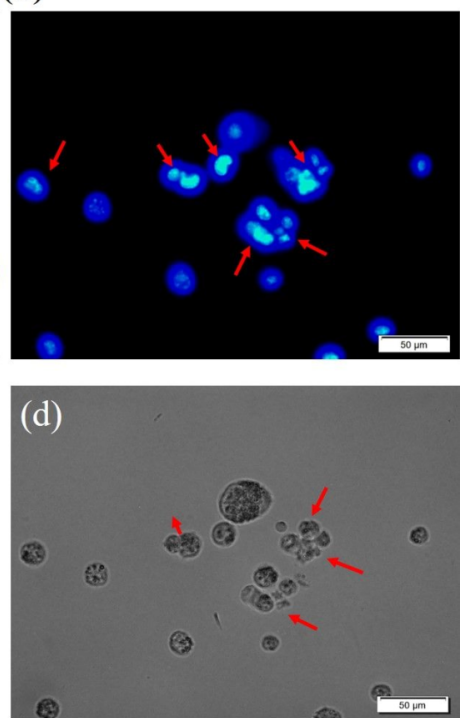

Fig. (4). Effects of SCBME (75mg/kg) on morphological appearances and nuclear damages of EAC cells. (a) and (c), represent fluorescence and optical microscopic of untreated EAC cells, whereas (b) and (d) represent SCBME treated EAC cells; (e) Agarose gel electrophoresis of EAC cell's genomic DNA for both control and treated mice which showed non-fragmented band for control (C) and the fragmented band for treated (T) EAC cells. $(A$ higher resolution / colour version of this figure is available in the electronic copy of the article).

the toxicity of tumourigenesis. Interestingly, these deteriorated parameters reverted towards the normal level when SCBME supplementation was given (Table 5).

\subsection{SCBME Induced Apoptosis of EAC Cells}

It was noted that nuclei of EAC cells were round, regular, and homogeneously stained with DAPI in control, whereas chromosome condensation, membrane blebbing, apoptotic body, and fragmented DNA were observed in SCBME treated EAC cells (Fig. 4). In addition, we found a non-fragmented distinct band on agarose gel for control EAC cell's genomic DNA, whereas a fragmented band in the case of SCBME treated cell's genomic DNA (Fig. 4e).
These results indicated that SCBME treatment could induce apoptosis in EAC cells.

\subsection{SCBME Induced Alteration in the Expression of Apoptosis- related Gene}

The expression of internal control GAPDH was consistent between the control and treated groups (Fig. 5a), whereas p53 was found to be overexpressed in SCBME treated EAC cells compared to control (Fig. 5b). Similarly, the expression of pro-apoptotic gene Bax was increased in SCBME treated EAC cells compared to control EAC cells (Fig. 5c). On the other hand, the expression of $\mathrm{Bcl}-2$, an anti-apoptotic gene, was lower compared to control (Fig. 5d). 
(a)

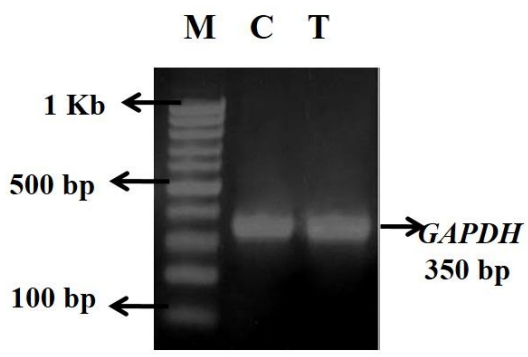

(c)

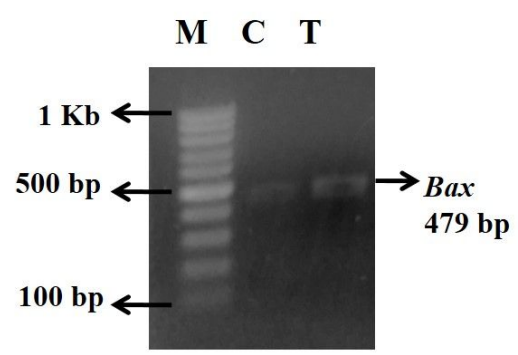

(e)

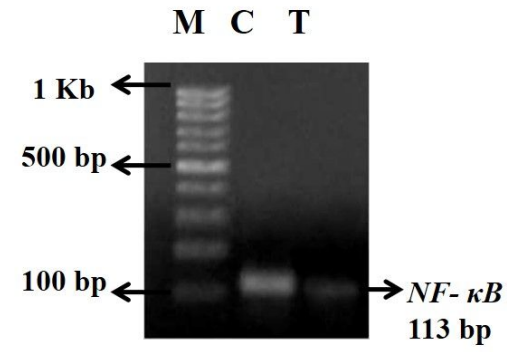

(b)

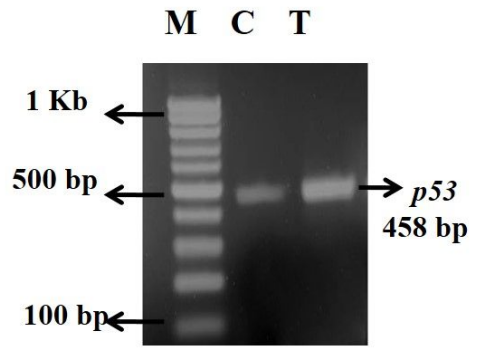

(d)

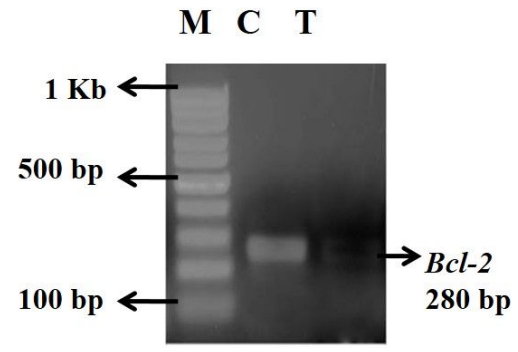

Fig. (5). Agarose gel electrophoresis of extracted DNA and PCR product from untreated and SCBME (75mg/kg) treated EAC cells. Lane (M), (C), (T) represent molecular marker, control, and SCBME treated, respectively. (a) Equal expression of GAPDH in case of both control and treated EAC cells; (b) Upregulation of $p 53$ genes in treated cells in comparisons to control; (c) Upregulation of Bax gene in treated cells in comparison to control; (d) Downregulation of Bcl2 gene in case of treatment; (e) Downregulation of $N F-\kappa B$ gene in case of treatment compared to control. (A higher resolution / colour version of this figure is available in the electronic copy of the article).

Interestingly, a decreased level of $N F-\kappa B$ expression in SCBME treated EAC cells was found (Fig. 5e). The results of gene amplification study reported that the treated mice showed up-regulation of p53 and up-regulation of pro-apoptotic gene Bax mRNA levels as well as down-regulation of $N F-\kappa B$ and anti-apoptotic gene $B c l-2$ mRNA levels (when compared with their respective control), which implied that SCBME inhibited EAC cells growth and proliferation by inducing apoptosis.

\section{DISCUSSION}

A growing number of experimental studies have suggested that the anticancer activity of plant materials is attributed to the presence of bioactive compounds with antioxidant potentialities [2628]. Phytochemical analysis revealed that SCBME possessed a high amount of polyphenols such as phenolics, flavonoids, flavonols, and proanthocyanidins, which reflected the antioxidant and anticancer properties observed in the present study. SCBME also contains a considerable amount of anthocyanin, $\beta$-carotene, and lycopene, which are well-known antioxidants and have been thought of as potent anticancer agents [14]. This study also revealed that
SCBME is a strong free radical scavenger activity and has potent antioxidant activity with a very strong potential to eradicate free radicals. SCBME also showed prominent dose-dependent reducing capacity in Ferric Reducing Antioxidant Power assay, which is supported by a previous study [29]. The $\mathrm{IC}_{50}$ value of $11.04 \mu \mathrm{g} / \mathrm{ml}$ in the DPPH assay is significantly lower than a previous finding $(600 \mu \mathrm{g} / \mathrm{ml})$ from Tamil Nadu, India [29]. It is suggested that variations in antioxidant content may result from different geographical positions.

It has been suggested that the compound having an $\mathrm{LC}_{50}$ value less than $250 \mu \mathrm{g} / \mathrm{ml}$ against brine shrimp lethality bioassay is a significantly active and useful candidate for further research [11]. Considering this, having an $\mathrm{LC}_{50}$ value of $98.07 \mu \mathrm{g} / \mathrm{ml}$, SCBME may be a potent source of biologically active compounds. GC-MS analysis suggested significant bioactive compounds in SCBME. Many of the identified compounds are known to possess anticancer activities [30-37]. For example, 2,4-Imidazolidinedione, one of the bioactive compounds found in SCBME, reported inhibiting the proliferation of human erythroleukemic K562 cells and human prostate cancer PC-3 cells through induction of apoptosis [30]. 
Canthaxanthin, another prominent bioactive compound of SCBME, appeared to prevent cancer initiation. It was suggested that dietary supplementation of Canthaxanthin resulted in a $65 \%$ reduction of mammary cancer in rats induced by dimethylbenzanthracene [31]. Carotene, another compound found in SCBME, has shown in vitro antiproliferative activity against $\mathrm{HepG} 2$ cells [32]. Cephalotaxine (CET), a natural alkaloid present in SCBME, was derived from the Chinese coniferous tree Cephalotaxushainanensis and found to have tumor cell growth inhibitory effect [33]. One of the Cephalotaxine ester called omacetaxinemepe succinate is FDA approved drug for both chronic- and blast-phase and in clinical trials [34]. Another compound present in SCBME was 9, 10-Anthracenedione which showed strong inhibition against fatty acid synthase expression in human breast cancer MDA-MB-231 cells [35]. Cyclohexanone was also found in SCBME, which had been reported to exert anticancer potential against various human carcinoma cell lines by inducing apoptosis $[36,37]$. The presence of these bioactive compounds in SCBME indicated that the noted significant anticancer activity could be the synergistic activity of these compounds against EAC cells.

Cell growth inhibition, reduction of tumor weight, increase in survival time and restoration of hematological parameter towards normal levels are considered as the reliable criteria for evaluating an anticancer drug $[21,22]$. We found that SCBME fulfils all these criteria when compared with data obtained by running a parallel experiment with a clinically-used anticancer drug (bleomycin at the dose $0.3 \mathrm{mg} / \mathrm{kg}$ ) (Fig. 3 \& Table 5). EAC-cell bearing mice were found to reduce hemoglobin concentrations and $\mathrm{RBC}$ counts gradually [21]. Administration of SCBME in EAC cell-bearing mice reversed all the altered hematological parameters more or less to normal level suggesting the protective action of SCBME on the haemopoietic system. These findings indicated the compatibility of SCBME as a natural anticancer agent.

Escaping of apoptosis is the early incidence in tumor growth, which allows the cell to proliferate abnormally and leading to the progression of cancer [38]. Therefore, the induction of apoptosis of cancer cells without damaging surrounding normal cells is one of the mechanisms of anticancer agents [39]. Hence, to study the underlying mechanism of the anticancer potential of SCBME, we evaluated its apoptotic efficiency. It was found that among the three doses, $75 \mathrm{mg} / \mathrm{kg}$ was more effective against EAC cells. Therefore, it was chosen to evaluate the apoptotic efficiency. Fluorescence and optical microscopy of SCBME treated EAC cells showed significant morphological changes, including cell membrane blebbing, the formation of apoptotic bodies, chromosomal condensation, and nuclear fragmentation. On the contrary, normal, round size cells and regular nucleus were observed in control mice (Fig. 4). These morphological alterations indicated the apoptosis of EAC cells. Further evaluation of EAC cells apoptosis was conducted by performing a DNA laddering test, which revealed fragmented bands in gel electrophoresis for SCBME treated mice's DNA. However, the DNA extracted from control mice showed a relatively unique and distinct band. The activation of the endogenous $\mathrm{Ca}^{2+1} \mathrm{Mg}^{2+}$ dependent endonucleases mediated the cleavage of inter-nucleosomes and generated oligonucleotide fragments, which is the most distinctive biochemical hallmark of apoptosis [25]. Thus, the appearance of fragmented bands in agarose gel implies the induction of apoptosis in EAC cells by SCBME treatment.

To investigate the mechanisms by which SCBME inhibited cell growth and promoted apoptosis in EAC cells, we analyzed the expression of some genes related to cell proliferation and apoptosis. Cancer cells can use a number of diverse strategies to evade apoptosis [39]. One of the common strategies is a disruption in the balance of pro-apoptotic and anti-apoptotic proteins due to an underexpression or over-expression of the pro-apoptotic proteins and anti-apoptotic proteins, respectively, or a combination of both [38, 39]. We focused on this strategy because several compounds present in SCBME as well as some antioxidants rich plant extracts are reported to induce apoptosis by activating intrinsic pathways of apoptosis [8, 21, 28, 30, 35]. Interestingly, we found that SCBME up-regulated pro-apoptotic gene $B a x$, tumor suppressor gene $p 53$ and down-regulated anti-apoptotic gene $B c l-2 . p 53$ is a nuclear transcription factor, which trans-activates numerous target genes involved in the induction of cell cycle arrest and/or apoptosis [40]. In addition, $p 53$ induces apoptosis through up-regulation of p53 responsive pro-apoptotic gene Bax. Furthermore, we observed the downregulation of $N F-\kappa B$ in SCBME treated EAC cells. In cancer cells, $N F-\kappa B$ is always constitutively activated and contributes to enhancing the proliferation and evasion of apoptosis [41, 42]. Thus, $N F-\kappa B$ is an important inhibitor of apoptosis and can protect cancer cells from death and inhibition of $N F-\kappa B$ and its signaling pathway could be a target of chemotherapy. Once activated and released into the nucleus, $N F-\kappa B$ trans-activates approximately 300 target genes encoding cytokines, growth factors, chemokines, and most importantly anti-apoptotic factors such as Bcl-2 [42]. Additionally, p53 and $N F-\kappa B$ can cause cell cycle arrest by regulating the expression of different cytokines and growth factors such as cyclin D and cyclin E, thereby inhibiting cell proliferation [43, 44]. Thus, a decreased level of $N F-\kappa B$ expression causes decreased expression of $B c l-2$. The present study revealed that SCBME up-regulated $p 53$ and $B a x$ as well as down-regulated $N F-\kappa B$ and $B c l-2$, which induced apoptosis of EAC cells.

\section{CONCLUSION}

In light of the above observations, it can be concluded that Syzygium cumini bark is a promising source of different bioactive phytochemicals, having significant antiproliferative, antioxidant and cytotoxic activities. The anticancer effects of SCBME could be due to the synergistic effects of various bioactive natural compounds, which appear to be mediated by multiple mechanisms, including induction of apoptosis through the regulation of target genes, p53, Bax, Bcl-2 and $N F-\kappa B$. Therefore, SCBME may be considered as a promising resource in cancer chemotherapy with a better host safety profile. In order to ascertain this as a potential source of anticancer drugs, it is necessary to carry out further experiments against human cancer cell lines both in vivo and in vitro.

\section{ETHICAL APPROVAL AND CONSENT TO PARTICIPATE}

The use of mice as an animal model for cancer research was approved by the Institutional Animal, Medical Ethics, Bio-Safety and Bio-Security Committee (IAMEBBC) for Experimentations on Animal, Human, Microbes, and Living Natural Sources (No. 125/320-IAMEBBC/IBSc), Institute of Biological Sciences, University of Rajshahi, Bangladesh.

\section{HUMAN AND ANIMAL RIGHTS}

No humans were used in this study. All research procedures involving were in accordance with the standards set forth in the 8th Edition of Guide for the Care and Use of Laboratory Animals (http://grants.nih.gov/grants/olaw/Guide-for-the-care-and-use-oflaboratory-animals.pdf).

\section{CONSENT FOR PUBLICATION}

Not applicable

\section{AVAILABILITY OF DATA AND MATERIALS}

Data incorporated in this manuscript are generated from primary research. 


\section{FUNDING}

This work was supported by grants from Dean of Science, Rajshahi University, Rajshahi-6205, Bangladesh (Grant No:1019(2)/ $169 / \mathrm{BM}$ ) and the grants from the Ministry of Science and Technology, Government of People's Republic of Bangladesh (Grant No. NST/2019-19/MSc/MS-355(3953)/Biol).

\section{CONFLICT OF INTEREST}

The authors declare no conflict of interest, financial or otherwise.

\section{ACKNOWLEDGEMENTS}

The authors are thankful to IICB Kolkata, India for providing EAC cells.

\section{REFERENCES}

[1] Bray, F.; Ferlay, J.; Soerjomataram, I.; Siegel, R.L.; Torre, L.A.; Jemal, A. Global cancer statistics 2018: GLOBOCAN estimates of incidence and mortality worldwide for 36 cancers in 185 countries. CA Cancer J. Clin., 2018, 68(6), 394-424. http://dx.doi.org/10.3322/caac.21492 PMID: 30207593

[2] Zhang, Q.Y.; Wang, F.X.; Jia, K.K.; Kong, L.D. Natural Product Interventions for Chemotherapy and Radiotherapy-Induced Side Effects. Front. Pharmacol., 2018, 9, 1253.

http://dx.doi.org/10.3389/fphar.2018.01253 PMID: 30459615

[3] Cleeland, C.S.; Allen, J.D.; Roberts, S.A.; Brell, J.M.; Giralt, S.A.; Khakoo, A.Y.; Kirch, R.A.; Kwitkowski, V.E.; Liao, Z.; Skillings, J. Reducing the toxicity of cancer therapy: recognizing needs, taking action. Nat. Rev. Clin. Oncol., 2012, 9(8), 471-478. http://dx.doi.org/10.1038/nrclinonc.2012.99 PMID: 22751283

[4] Safarzadeh, E.; Sandoghchian Shotorbani, S.; Baradaran, B. Herbal medicine as inducers of apoptosis in cancer treatment. Adv. Pharm. Bull., 2014, 4(1)(Suppl. 1), 421-427. PMID: 25364657

[5] Newman, D.J.; Cragg, G.M. Natural products as sources of new drugs over the last 25 years. J. Nat. Prod., 2007, 70(3), 461-477. http://dx.doi.org/10.1021/np068054v PMID: 17309302

[6] Kasote, D.M.; Katyare, S.S.; Hegde, M.V.; Bae, H. Significance of antioxidant potential of plants and its relevance to therapeutic applications. Int. J. Biol. Sci., 2015, 11(8), 982-991. http://dx.doi.org/10.7150/ijbs.12096 PMID: 26157352

[7] Saxena, A.; Saxena, A.K.; Singh, J.; Bhushan, S. Natural antioxidants synergistically enhance the anticancer potential of AP9-cd, a novel lignan composition from Cedrus deodara in human leukemia HL-60 cells. Chem. Biol. Interact., 2010, $188(3), 580-590$. http://dx.doi.org/10.1016/j.cbi.2010.09.029 PMID: 20932957

[8] Alam, A.K.; Hossain, A.S.; Khan, M.A.; Kabir, S.R.; Reza, M.A.; Rahman, M.M.; Islam, M.S.; Rahman, M.A.; Rashid, M.; Sadik, M.G. The Antioxidative Fraction of White Mulberry Induces Apoptosis through Regulation of p53 and NFKB in EAC Cells. PLoS One, 2016, $11(12)$, e 0167536.

http://dx.doi.org/10.1371/journal.pone.0167536 PMID: 27936037

[9] Haque, M.A.; Islam, M.U.A. Pleurotus highking Mushroom Induces Apoptosis by Altering the Balance of Proapoptotic and Antiapoptotic Genes in Breast Cancer Cells and Inhibits Tumour Sphere Formation. Medicina (B. Aires), 2019, 55(11), 716. http://dx.doi.org/10.3390/medicina55110716

[10] Deepa, M.; Sureshkumar, T.; Satheeshkumar, P.K.; Priya, S. Antioxidant rich Morus alba leaf extract induces apoptosis in human colon and breast cancer cells by the downregulation of nitric oxide produced by inducible nitric oxide synthase. Nutr. Cancer, 2013, 65(2), 305-310.

http://dx.doi.org/10.1080/01635581.2013.748924 PMID: 23441618

[11] Islam, M.S.; Rahi, M.S.; Jahangir, C.A.; Rahman, M.H.; Jerin, I.; Amin, R.; Hoque, K.M.F.; Reza, M.A. In Vivo Anticancer Activity of Basella alba Leaf and Seed Extracts against Ehrlich's Ascites Carcinoma (EAC) Cell Line. Evid. Based Complement. Alternat. Med., 2018, 2018, 1537896.

http://dx.doi.org/10.1155/2018/1537896 PMID: 30581479

[12] Ayyanar, M.; Subash-Babu, P. Syzygium cumini (L.) Skeels: a review of its phytochemical constituents and traditional uses. Asian Pac. J. Trop. Biomed., 2012, 2(3), 240-246.
Charepalli, V.; Reddivari, L.; Vadde, R.; Walia, S.; Radhakrishnan, S.; Vanamala, J.K. Eugenia jambolana (Java Plum) Fruit Extract Exhibits Anti-Cancer Activity against Early Stage Human HCT116 Colon Cancer Cells and Colon Cancer Stem Cells. Cancers (Basel), 2016, 8(3), 29

http://dx.doi.org/10.3390/cancers8030029 PMID: 26927179

[16] Das, P.K.; Siddika, M.A.; Asha, S.Y.; Aktar, S.; Islam, F.; Khanam, J.A.; Rakib, M.A. Investigation of phytochemicals and antioxidant activities in the leaves methanolic extract from Moringa oleifera plants grown in Bangladesh. J. Pharmacogn. Phytochem., 2019, 8(4), 2502-2508.

[17] Yesmin, R.; Das, P.K.; Belal, H.; Aktar, S.; Ayesha, M.A.; Rakib, M.A.; Islam, F.; Khanam, J.A. In vitro antioxidant and antidiabetic assessment of extracts from the bark of Michelia champaca, a medicinal plant in bangladesh. W.J. PS (Wash., D.C.), 2019, 8(9), 1505-1526.

[18] Vats, S.; Gupta, T. Evaluation of bioactive compounds and antioxidant potential of hydroethanolic extract of Moringa oleifera Lam. from Rajasthan, India. Physiol. Mol. Biol. Plants, 2017, 23(1), 239-248. http://dx.doi.org/10.1007/s12298-016-0407-6 PMID: 28250599

[19] Islam, F.; Raihan, O.; Chowdhury, D.; Khatun, M.; Zuberi, N.; Khatun, L.; Brishti, A.; Bahar, E. Apoptotic and antioxidant activities of methanol extract of Mussaenda roxburghii leaves. Pak. $J$. Pharm. Sci., 2015, 28(6), 2027-2034.

PMID: 26639496

[20] Islam, F.; Khatun, H.; Ghosh, S.; Ali, M.M.; Khanam, J.A. Bioassay of Eucalyptus extracts for anticancer activity against Ehrlich ascites carcinoma (eac) cells in Swiss albino mice. Asian Pac. J. Trop. Biomed., 2012, 2(5), 394-398.

http://dx.doi.org/10.1016/S2221-1691(12)60063-X PMID: 23569937

[21] Islam, F.; Khanam, J.A.; Khatun, M.; Zuberi, N.; Khatun, L.; Kabir, S.R.; Reza, M.A.; Ali, M.M.; Rabbi, M.A.; Gopalan, V.; Lam, A.K. A p-menth-1-ene-4,7-diol (EC-1) from Eucalyptus camaldulensis Dhnh. triggers apoptosis and cell cycle changes in Ehrlich ascites carcinoma cells. Phytother. Res., 2015, 29(4), 573-581. http://dx.doi.org/10.1002/ptr.5288 PMID: 25583285

[22] Islam, F.; Khatun, H.; Khatun, M.; Ali, S.M.; Khanam, J.A. Growth inhibition and apoptosis of Ehrlich ascites carcinoma cells by the methanol extract of Eucalyptus camaldulensis. Pharm. Biol., 2014, 52(3), 281-290.

http://dx.doi.org/10.3109/13880209.2013.834365 PMID: 24102623

[23] Yesmin, R.; Das, P.K.; Belal, H.; Aktar, S.; Siddika, M.A.; Asha, S.; Habib, F.; Rakib, M.A.; Islam, F. Anticancer Potential of Michelia champaca Linn. Bark Against Ehrlich As-cites Carcinoma (EAC) Cells in Swiss Albino Mice. Nat. Prod. J., 2020, 10, 1-5.

[24] Mandelkow, R.; Gümbel, D.; Ahrend, H.; Kaul, A.; Zimmermann, U.; Burchardt, M.; Stope, M.B. Detection and quantification of nuclear morphology changes in apoptotic cells by fluorescence microscopy and subsequent analysis of visualized fluorescent signals. Anticancer Res., 2017, 37(5), 2239-2244.

http://dx.doi.org/10.21873/anticanres.11560 PMID: 28476788

[25] Zahan, R.; Rahi, M.S.; Sheikh, M.C.; Miyatake, R.; Zangrando, E.; Naz, T.; Islam, M.A.; Reza, M.A. Design, synthesis and X-ray structural studies of novel [acetonitrile-benzyl-3-N-(2, 4 dihydroxyphenylmethylene) hydrazinecarbodithioato- $\left.\kappa 3-\mathrm{N}^{\prime}, \quad \mathrm{S}, \mathrm{O}\right]$ nickel (11) complex that potently inhibit cell proliferation through regulation of apoptosis related genes. Appl. Organomet. Chem., 2019, 33(1), e4601.

http://dx.doi.org/10.1002/aoc.4601

[26] Lamoral-Theys, D.; Pottier, L.; Dufrasne, F.; Nève, J.; Dubois, J.; Kornienko, A.; Kiss, R.; Ingrassia, L. Natural polyphenols that display anticancer properties through inhibition of kinase activity. Curr. Med. Chem., 2010, 17(9), 812-825.

http://dx.doi.org/10.2174/092986710790712183 PMID: 20156174

[27] Scalbert, A.; Manach, C.; Morand, C.; Rémésy, C.; Jiménez, L. Dietary polyphenols and the prevention of diseases. Crit. Rev. Food Sci. Nutr., 2005, 45(4), 287-306. http://dx.doi.org/10.1080/1040869059096 PMID: 16047496 
[28] Niedzwiecki, A.; Roomi, M.W.; Kalinovsky, T.; Rath, M. Anticancer Efficacy of Polyphenols and Their Combinations. Nutrients, 2016, $8(9), 552$.

http://dx.doi.org/10.3390/nu8090552 PMID: 27618095

[29] Jayachandra, K. In vitro Antioxidant activity of Methanolic Extract of Syzygium cumini Linn. Bark. A.J.B.P.S., 2012, 2(12), 45.

[30] Wang, G.; Wang, Y.; Wang, L.; Han, L.; Hou, X.; Fu, H.; Fang, H. Design, synthesis and preliminary bioactivity studies of imidazolidine-2,4-dione derivatives as Bcl-2 inhibitors. Bioorg. Med. Chem., 2015, 23(23), 7359-7365. http://dx.doi.org/10.1016/j.bmc.2015.10.023 PMID: 26558516

[31] Grubbs, C.J.; Eto, I.; Juliana, M.M.; Whitaker, L.M. Effect of canthaxanthin on chemically induced mammary carcinogenesis. Oncology, 1991, 48(3), 239-245.

http://dx.doi.org/10.1159/000226935 PMID: 1902560

[32] Hou, J.; Cui, H.L. In Vitro Antioxidant, Antihemolytic, and Anticancer Activity of the Carotenoids from Halophilic Archaea. Curr. Microbiol., 2018, 75(3), 266-271.

http://dx.doi.org/10.1007/s00284-017-1374-z PMID: 29038844

[33] Efferth, T.; Sauerbrey, A.; Halatsch, M.E.; Ross, D.D.; Gebhart, E. Molecular modes of action of cephalotaxine and homoharringtonine from the coniferous tree Cephalotaxus hainanensis in human tumor cell lines. Naunyn Schmiedebergs Arch. Pharmacol., 2003, 367(1), 56-67. http://dx.doi.org/10.1007/s00210-002-0632-0 PMID: 12616342

[34] Trendowski, M. Recent Advances in the Development of Antineoplastic Agents Derived from Natural Products. Drugs, 2015, 75(17), 1993-2016. http://dx.doi.org/10.1007/s40265-015-0489-4 PMID: 26501980

[35] Wei, G.; Chen, H.; Nie, F.; Ma, X.; Jiang, H. 1, 3, 6-Trihydroxy-7Methyl-9, 10-Anthracenedione Isolated from genus Lindera with Anti-Cancer Activity. Anticancer. Agents Med. Chem., 2017, 17(11), 1604-1607.

http://dx.doi.org/10.2174/1871520615666150914114649 PMID: 27291048

[36] Zhang, L.; Chen, Q.; Hou, G.; Zhao, W.; Hou, Y. Hydroxylsubstituted double Schiff-base condensed 4-piperidone/ cyclohexanones as potential anticancer agents with biological evaluation. J. Enzyme Inhib. Med. Chem., 2019, 34(1), 264-271. http://dx.doi.org/10.1080/14756366.2018.1501042 PMID 30734613

[37] Bonner, M.Y.; Arbiser, J.L. The antioxidant paradox: what are antioxidants and how should they be used in a therapeutic context for cancer. Future Med. Chem, 2014, 6(12), 1413-1422. PMID: 27019364

[38] Pistritto G. Trisciuoglio D. Ceci C. Garufi A. D'Orazi G.. nApoptosis as anticancer mechanism: function and dysfunction of its modulators and targeted therapeutic strategies Aging (Albany NY), 2016, 8(4), 603-619. 2016, 8(4), 603-619. http://dx.doi.org/10.3390/ijms19020448 PMID: 29393886

[39] Pfeffer, C.M.; Singh, A.T.K. Apoptosis: A Target for Anticancer Therapy. Int. J. Mol. Sci., 2018, $19(2), 448$. http://dx.doi.org/10.3390/ijms19020448 PMID: 29393886

[40] Ozaki, T.; Nakagawara, A. Role of p53 in cell death and human cancers. Cancers (Basel), 2011, 3(1), 994-1013.

http://dx.doi.org/10.3390/cancers3010994 PMID: 24212651

[41] Perkins, N.D. The diverse and complex roles of NF- $\kappa \mathrm{B}$ subunits in cancer. Nat. Rev. Cancer, 2012, 12(2), 121-132. http://dx.doi.org/10.1038/nrc3204 PMID: 22257950

[42] Karin, M.; Cao, Y.; Greten, F.R.; Li, Z.W. NF-kappaB in cancer: from innocent bystander to major culprit. Nat. Rev. Cancer, 2002 , 2(4), 301-310.

http://dx.doi.org/10.1038/nrc780 PMID: 12001991

[43] Chen, J. The Cell-Cycle Arrest and Apoptotic Functions of p53 in Tumor Initiation and Progression. Cold Spring Harb. Perspect. Med., 2016, 6(3), a026104.

http://dx.doi.org/10.1101/cshperspect.a026104 PMID: 26931810

[44] Srivastava, S.K.; Singh, S.V. Cell cycle arrest, apoptosis induction and inhibition of nuclear factor kappa B activation in antiproliferative activity of benzyl isothiocyanate against human pancreatic cancer cells. Carcinogenesis, 2004, 25(9), 1701-1709. http://dx.doi.org/10.1093/carcin/bgh179 PMID: 15117814 